\title{
Antioxidant Properties of Spirulina (Arthospira) platensis Cultivated Under Different Temperatures and Nitrogen Regimes
}

\author{
Luciane Maria Colla, Eliana Badiale Furlong, Jorge Alberto Vieira Costa* \\ Laboratório de Engenharia Bioquímica; Departamento de Química; Fundação Universidade Federal do Rio \\ Grande - FURG; C. P. 474; dqmjorge@furg.br; 96201-900; Rio Grande - RS - Brasil
}

\begin{abstract}
The main aim of this work was to investigate the effects of temperature and nitrogen concentration on the antioxidant potential of extracts from Spirulina (Arthospira) platensis biomass. S. platensis biomass obtained at $35^{\circ} \mathrm{C}$ and with $1.875 \mathrm{~g} . \mathrm{L}^{-1}$ or $2.5 \mathrm{~g} . \mathrm{L}^{-1}$ of sodium nitrate in the culture medium presented higher concentrations of phenolic compounds. The antioxidant potential of methanol extracts of biomass on the enzymatic browning caused by peroxidase were 29 and 35\%, respectively, being the reduction related to the amount of phenolic compounds present in this extract.
\end{abstract}

Keywords: Antioxidant, phenolic compounds, Spirulina (Arthospira) platensis

\section{INTRODUCTION}

The use of antioxidant nutritional and food supplements has been the subject of many studies (Estrada et al., 2001), with several findings that phenolic compounds can not only increase the shelf-life of foods but also act as antioxidants in many biological systems (Milié et al., 1998). Mediterranean diets have been associated with a low incidence of cardiovascular disease and cancer, such effects being thought to be due to the fact that such diets are rich in fruits and vegetables which contain large amounts of vitamins, flavonols and polyphenols (Benavente-García et al., 1999).

Cyanobacteria of the genus Spirulina have been studied not only because of the potential as a protein source but also because of their therapeutic properties, which include reports of the ability of preparations of this cyanobacterium to prevent and inhibit cancers, to decrease blood cholesterol levels, stimulate the immunological system, to reduce the nefrotoxicity of pharmaceuticals and toxic metals and provide protection against the harmfull effects of radiation (Belay et al., 1993).

Phenolic compounds have been extensively studied for their antioxidant properties not only in fruits and vegetables (Amaral et al., 1995; Frankel et al., 1995; Yen and Chen, 1995; Yoshino and Murakami, 1998; Duval and Shetty, 2001) but also in cyanobacteria. For example, Miranda et al. (1998) studied the antioxidant activity of carotenoids, phenolics and tocopherols extracted from S.maxima and found that the phenolic compounds responsible for the antioxidant properties of the $S$. maxima extracts were organic acids (caffeic, chlorogenic, quimic, salicylic, synaptic and trans-cinnamic) which acted individually or synergistically, while Estrada et al.

\footnotetext{
* Author for correspondence
} 
(2001) demonstrated the antioxidant activity of the phycobiliproteins phycocyanin and alophycocyanin present in Spirulina biomass.

The aim of this work was to investigate the influence of the temperature and nitrogen concentration on the production of phenolics by Arthospira platensis and to assess the antioxidant activity of these phenolics based on their capacity to prevent peroxidase-induced browning of guayacol.

\section{MATERIAL AND METHODS}

\section{Microorganism and culture medium}

Spirulina (Arthospira) platensis strain LEB-52 (Costa et al., 2003; Costa et al., 2002) was maintained on a standard synthetic medium (Zarrouk, 1966) containing 2.5 g.L $\mathrm{L}^{-1}$ sodium nitrate as nitrogen source. This medium was also used to prepare inoculum for batch cultivation. To study the effect of the inorganic nitrogen concentration on the growth of the strain LEB-52 in batch culture a modified Zarrouk's medium was used where the concentration of sodium nitrate
$\left(\mathrm{NaNO}_{3}\right)$ was $0.625,1.250,1.875$ or 2.500 g.L ${ }^{-1}$. All the reagents used were of analytical grade, obtained from the Merck Chemical Co. (Darmstadt, Germany) or the Synth Chemical Co. (São Paulo, Brazil).

\section{Cultivation}

The experiments with strain LEB-52 were carried out in 20-litres photo-bioreactors containing an initial medium volume of 14-litres and an initial biomass concentration of $0.15 \mathrm{~g} . \mathrm{L}^{-1}$. The cultures were air-mixed using an air flux of 170 L.h $^{-1}$ provided by diaphragm pumps. The photobioreactors were maintained in a greenhouse and illuminated with daylight-type $40 \mathrm{~W}$ fluorescent tubes (Osram, Brazil) providing 1,900 lux of illuminance measured by a luximeter (Costa et al., 2000) under a $12 \mathrm{~h}$ light/dark photoperiod. The fermentation runs were set up according to a multilevel factorial design (MFD) in which the concentration of sodium nitrate in the Zarrouk's medium was set at four different levels and the temperature at 30 and $35^{\circ} \mathrm{C}$ (Table 1); all runs were triplicated.

Table 1 - Factorial design matrix for the fermentation runs.

\begin{tabular}{c|cc|c|c}
\hline \multicolumn{3}{c}{ Variable } & \multicolumn{3}{c}{ Temperature } \\
\hline \multirow{2}{*}{ Run } & \multicolumn{2}{c}{ Inorganic nitrogen concentration } & \multicolumn{3}{c}{$\left(\mathbf{X}_{\mathbf{2}}\right)$} \\
\hline 1 & \multicolumn{1}{c}{ Sodium nitrate $(\mathbf{g} / \mathbf{l})$} & $\left(\mathbf{X}_{\mathbf{1}}\right)$ & ${ }^{\circ} \mathbf{C}$ & -1 \\
2 & 0.625 & -1 & 30 & -1 \\
3 & 1.250 & -0.33 & 30 & -1 \\
4 & 1.875 & +0.33 & 30 & -1 \\
5 & 2.500 & +1 & 30 & +1 \\
6 & 0.625 & -1 & 35 & +1 \\
7 & 1.250 & -0.33 & 35 & +1 \\
8 & 1.875 & +0.33 & 35 & +1 \\
\hline
\end{tabular}

$\mathrm{X}_{1}$ : Variable code for sodium nitrate concentration

$\mathrm{X}_{2}$ : Variable code for temperature

At the end of each run, the replicate cultures were combined and the $S$. platensis biomass was separated by filtration, washed with distilled water to remove soluble salts, resuspended in distilled water and pelleted by centrifuging at $15,000 \mathrm{xg}$ before being lyophilized and stored at $-20^{\circ} \mathrm{C}$ until needed.

\section{Lipid and protein determinations in biomass}

Lipids were extracted from a known quantity of biomass using a 2:1 chloroform/methanol mixture and the lipid content was determined gravimetrically (Folch \& Lees, 1957). Protein was determined by the micro-Kjeldahl method according to AOAC standard methods (AOAC, 1995). Three replicates were analyzed for each lyophilized biomass sample.

\section{Antioxidant activity}

Antioxidant activity of the lyophilized S. platensis was determined by extracting the total phenolics present with methanol and calculating the antioxidant activity of the extract by measuring the inhibition of peroxidase-induced browning of guayacol. Phenolics were extracted by agitating $1 \mathrm{~g}$ of lyophilized $S$. platensis with methanol at $25^{\circ} \mathrm{C}$. 
The methanolic extract was purified with hexane for extraction of non polar compounds. The lower phase was added of barium hydroxide and zinc sulfate to precipitation of others interferents (Furlong et al., 2003). Total phenols of the extracts were assessed using the Folin-Ciocalteau method (Singleton and Rossi, 1965) as modified by Furlong et al., (2003). The antioxidant activity of the $S$. platensis phenol-containing methanol extracts was assessed using potato peroxidase and guayacol as substrate. Peroxidase was extracted from potatoes according to the method of Valderrama et al., (2001) modified as follows: 100 $\mathrm{g}$ of peeled potato was mixed for 2 min with 100 $\mathrm{mL}$ of distilled, filtered and the peroxidase precipitated from the filtrate with $300 \mathrm{~mL}$ of acetone. The peroxidase were recovered by centrifugation and dissolved in $0.01 \%$ EDTA. The antioxidant activity of the $S$. platensis methanol extracts was measured based on the inhibition the ability of peroxidase to cause the browning of guayacol using a reaction mixture consisting of 5 $\mathrm{mL}$ of phosphate buffer $(\mathrm{pH} 6), 1 \mathrm{~mL}$ of potato peroxidase, $2 \mathrm{~mL}$ of a $0.5 \%(\mathrm{w} / \mathrm{v})$ solution of guayacol in ethanol, $1 \mathrm{~mL}$ of $0.08 \%(\mathrm{v} / \mathrm{v})$ hydrogen peroxide and $2 \mathrm{~mL}$ of $S$. platensis methanol extract. Controls used the same mixture except that the methanol extract was replaced by 2 $\mathrm{mL}$ of distilled water. The reactions were carried out for $0,5,10,20,30$ and $40 \mathrm{~min}$ at $37^{\circ} \mathrm{C}$ and $\mathrm{pH}$ 6.0 and stopped with $2 \mathrm{~mL}$ of $0.5 \mathrm{~N}$ hydrochloric acid. The absorbance was measured at $470 \mathrm{~nm}$ in a Varian Cary 100 spectrophotometer.

The antioxidant potential (AP) of the phenolcontaining $S$. platensis methanol extracts was calculated for each reaction time $(0,5,10,20,30$ and $40 \mathrm{~min}$ ) according to the decrease in browning as follows: $\mathrm{AP}=\mathrm{A}_{\mathrm{T} 2-\mathrm{i}}-\mathrm{AC}_{\mathrm{T} 1-\mathrm{i}} / \mathrm{A}_{\mathrm{T} 2-\mathrm{i}} \mathrm{x} 100$ where $A_{T 2-i}$ is the absorbance of the control reaction mixture at time $\mathrm{i}$ and $\mathrm{AC}_{\mathrm{T} 1-\mathrm{i}}$ the corrected absorbance of the reaction mixture containing $S$. platensis methanol extract at time $\mathrm{i}$. The corrected absorbance was calculated as $\mathrm{AC}_{\mathrm{T} 1-\mathrm{i}}=\mathrm{A}_{\mathrm{T} 1-\mathrm{i}}$ $\left(\mathrm{A}_{T 1-\mathrm{B}}-\mathrm{A}_{\mathrm{T2}-\mathrm{B}}\right)$ where $\mathrm{A}_{\mathrm{T1- \textrm {i }}}$ is the absorbance of the reaction mixture containing $S$. platensis methanol extract at time $\mathrm{i}, \mathrm{A}_{\mathrm{T} 1-\mathrm{B}}$ the absorbance of the reaction mixture containing $S$. platensis methanol extract at time zero and $A_{\mathrm{T} 2-\mathrm{B}}$ the absorbance of the control reaction mixture at time zero.

\section{Experimental design and statistical analysis}

The multilevel factorial design (Table 1) data was analyzed using analysis of variance (ANOVA) to compare the data and calculate probability values.

\section{RESULTS AND DISCUSSION}

Phenol-containing methanol extracts of lyophilized S. platensis reduced the amount of peroxidase-induced browning of guayacol (Figure 1). Table 2 showed that the quantity of phenolic compounds produced by Arthospira platensis in each run was related to the antioxidant potential (AP) of the phenol-containing $S$. platensis methanol extracts. Higher concentrations of phenols resulted in less browning and higher antioxidant potential (AP). The antioxidant potential was calculated using the 10 min reactiontime data $\left(\mathrm{AP}_{10}\right)$.

The highest quantities of phenolic compounds was produced at $35^{\circ} \mathrm{C}$ in medium supplemented with 1.875 or 2.5 g. $\mathrm{L}^{-1}$ of sodium nitrate. The antioxidant potentials of the extracts obtained from S. platensis grown under these conditions were 29 and $35 \%$ for the medium containing 1.875 g.L ${ }^{-1}$ and 2.5 g.L. ${ }^{-1}$ of sodium nitrate (Table 2), respectively.

According to Miranda et al. (1998), the main phenolic compounds found in Spirulina were salicylic, trans-cinnamic, synaptic, chlorogenic, quimic and caffeic acids. However, the metabolic pathways for the formation of these compounds in cyanobacteria and their importance were still unknown.

For green plants, Rechner et al. (2001) reported that phenylalanine could be converted by an ammonia lyase to trans-cinnamic acid that was transformed to cumaric acid which was in turn converted to caffeic acid. These compounds are used to produce flavonoids, with antioxidant activity. According to Duval \& Shetty (2001), biosynthetic pathways that lead to the formation of flavonols and phenylpropanols in plants are related to the pentose-phosphate (Calvin) cycle, and the amounts synthesized are characteristic of each organism. 


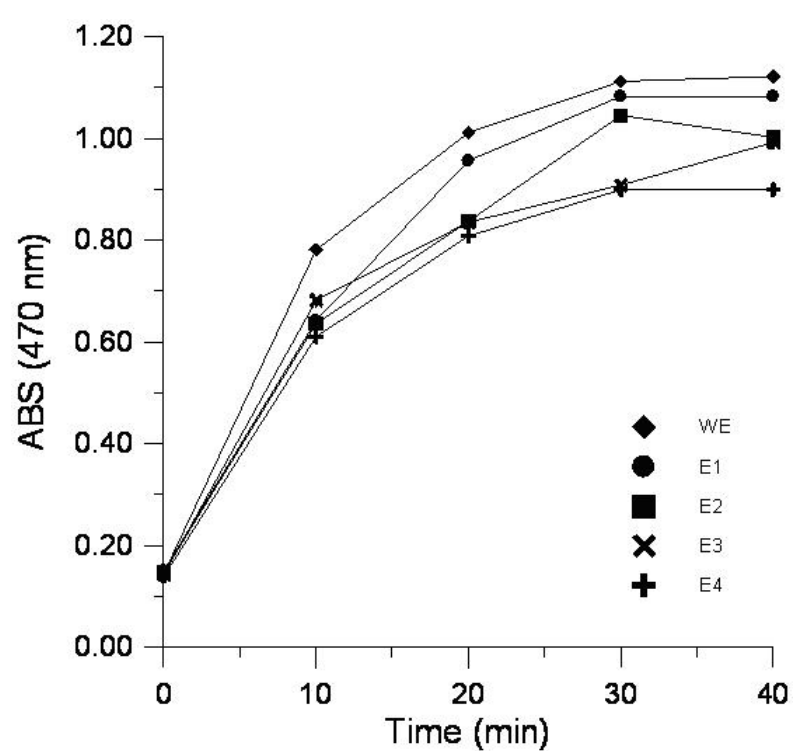

(a)

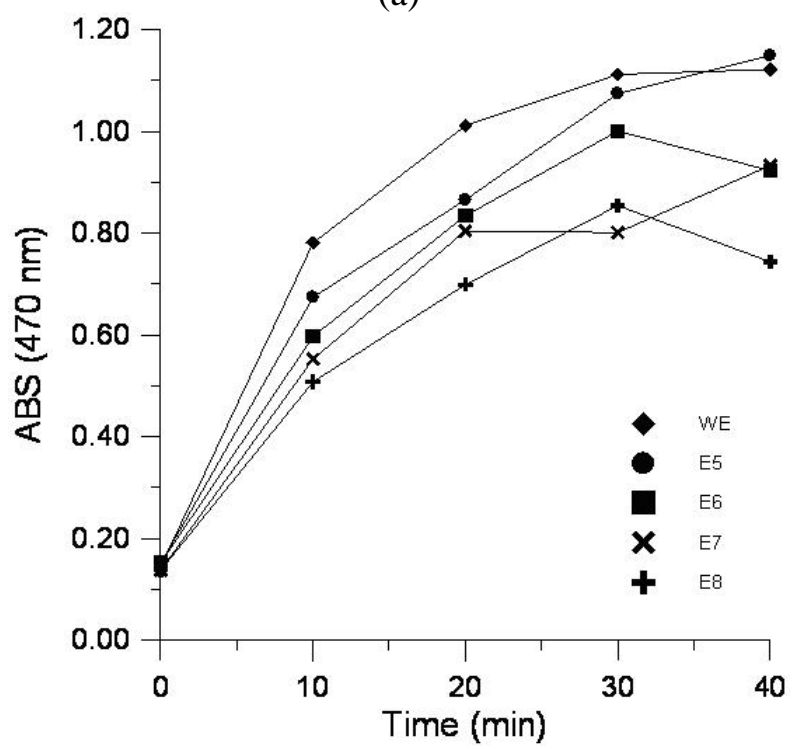

(b)

Figure 1 - Peroxidase-induced browning of guayacol in reaction mixtures with and without addition of methanol extracted containing phenols obtained of Spirulina platensis. Biomass obtained at (a) $30^{\circ} \mathrm{C}$, (b) $35^{\circ} \mathrm{C}$. WE $=$ Controls without $S$. platensis methanol extract. E = extract, where E1 to E8 represent the methanol extracts obtained from $S$. platensis produced in runs 1 to 8 .

Statistical analysis of the results presented in Table 2 indicated that both sodium nitrate concentration and temperature had a significant effect not only as regards variation in the quantity of phenolic compounds present in the lyophilized $S$. platensis biomass $(p<0.001$ for nitrate and $p=0.004$ for temperature) but also in the antioxidant potential of the phenol-containing $S$. platensis methanol extracts $(\mathrm{p}<0.001$ for both factors). There were significant interactions regarding the content of phenolic compounds and antioxidant potential at the $99 \%$ confidence interval, indicating that the interaction between these variables should be investigated in more detail.

The two-way interaction plots (Figures 2 and 3) show the effects of sodium nitrate concentration on the amount of phenolic compounds (Figure 2) and the antioxidant potential of phenol-containing methanol extracts of $S$. platensis cultivated at 30 and $35^{\circ} \mathrm{C}$. Higher sodium nitrate concentrations 
(1.875 and 2.500 g.L $\left.\mathrm{L}^{-1}\right)$ promoted higher levels phenolic compounds in S. platensis grown at $35^{\circ} \mathrm{C}$ (Figure 2). Sodium nitrate and temperature had a similar influence on the protein, lipid and phenolic content. In the runs 1 to $6 S$. platensis presented an average of $59 \%$ of protein and $7 \%$ of lipid and runs 7 and 8 an average of $68 \%$ of protein and $10 \%$ of lipid.

Table 2 - Total phenolic compounds produced by Spirulina platensis in each run and the antioxidant potential (AP) of the phenol-containing S. platensis methanol extracts as calculated using the 10 min reaction-time data $\left(\mathrm{AP}_{10}\right)$.

\begin{tabular}{ccc}
\hline Run & $\begin{array}{c}\text { Phenolic compounds* } \\
(\boldsymbol{\mu g} \text { per gram of } \text { S. platensis biomass })\end{array}$ & $\begin{array}{c}\mathbf{A P}_{\mathbf{1 0}} \\
\mathbf{( \% )}\end{array}$ \\
\hline $30^{\circ} \mathrm{C}$ & $3,087 \pm 0,258$ & 17.8 \\
1 & $3,661 \pm 0,266$ & 18.5 \\
2 & $3,268 \pm 0,394$ & 20.6 \\
3 & $3,782 \pm 0,299$ & 21.8 \\
4 & & \\
$35^{\circ} \mathrm{C}$ & & 17.6 \\
5 & $2,458 \pm 0,222$ & 23.5 \\
6 & $2,417 \pm 0,213$ & 29.2 \\
7 & $4,997 \pm 0,373$ & 35.0 \\
\hline
\end{tabular}

*Mean \pm standard deviation

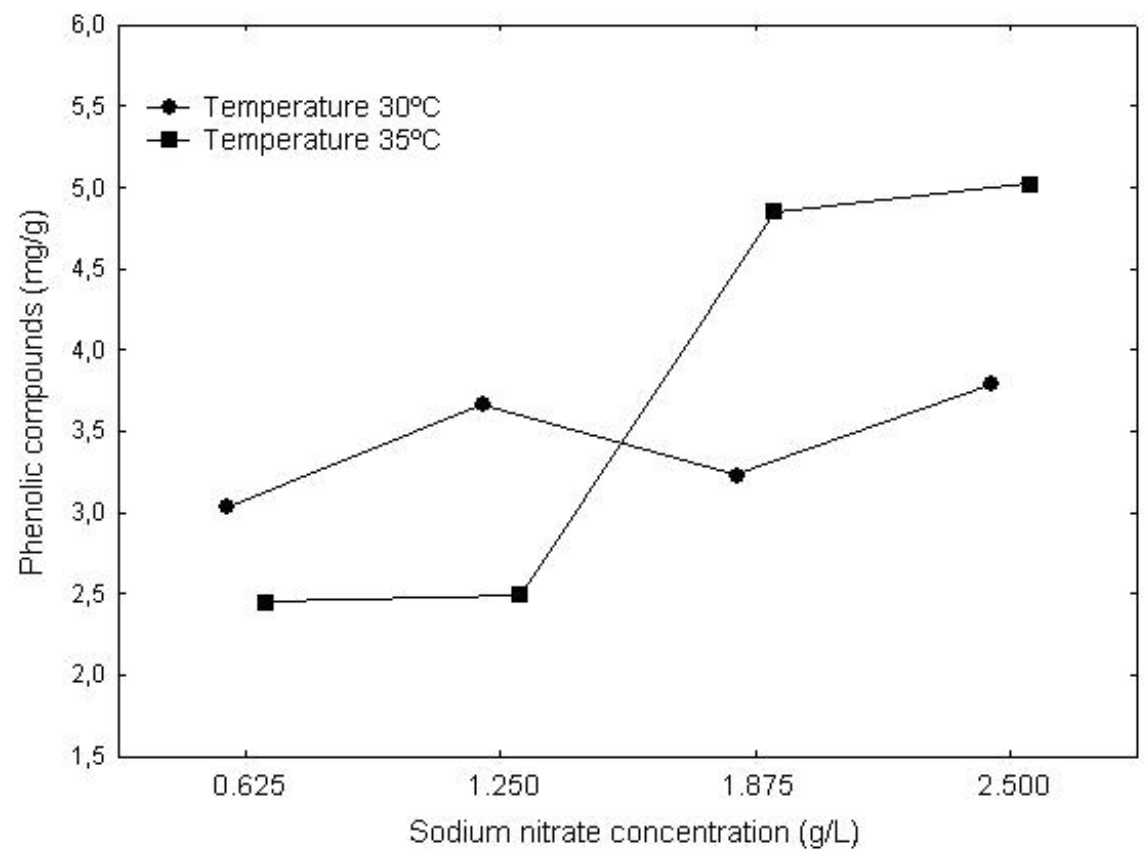

Figure 2 - Relationship between sodium nitrate concentration and the amount of phenolic compounds in Spirulina platensis cultivated at 30 and $35^{\circ} \mathrm{C}$. 


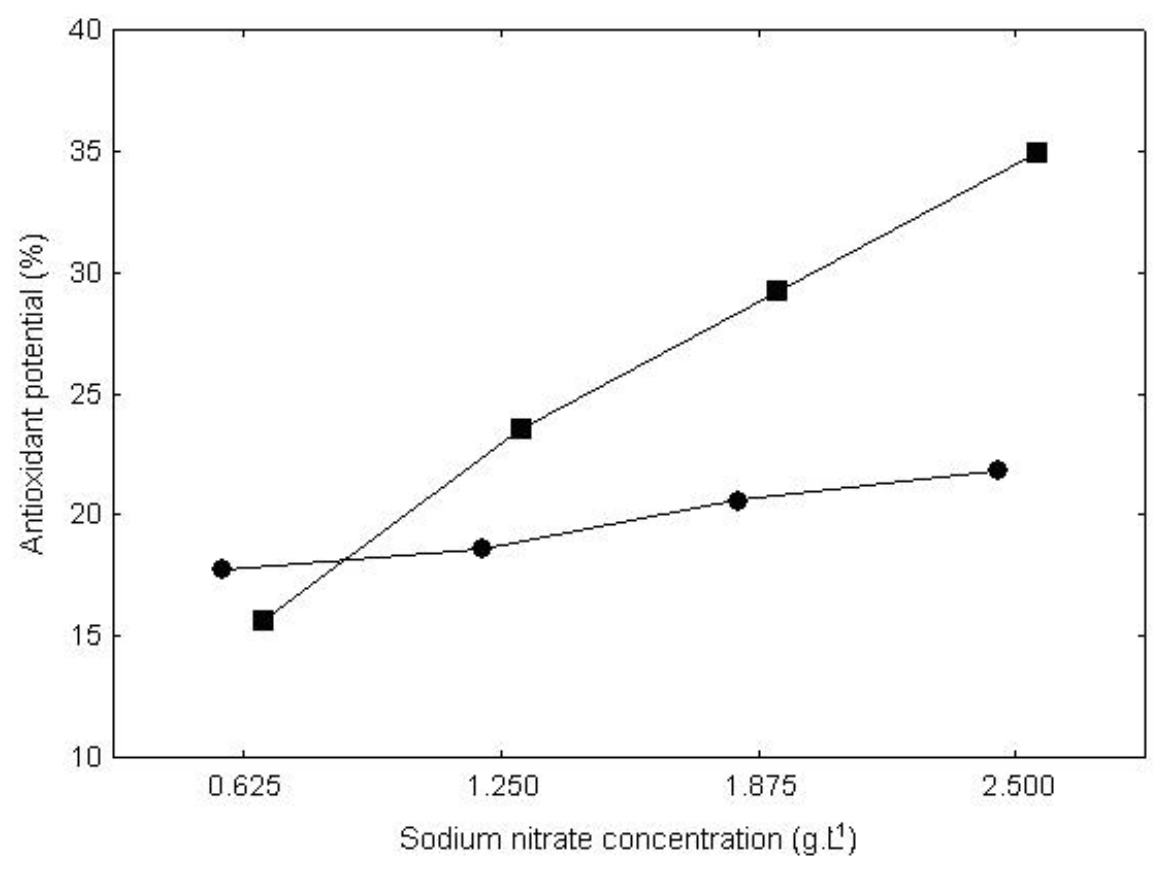

Figure 3 - Relationship between sodium nitrate concentration and the antioxidant potential of phenol-containing methanol extracts of Spirulina platensis cultivated at 30 and $35^{\circ} \mathrm{C}$.

Although the mechanisms used by cyanobacterium to synthesize phenolic compounds and their metabolic functions in cells were still unknown, at $35^{\circ} \mathrm{C}$ there was a significant increase in the quantity of phenolic compounds synthesized by the cells and this increase was also related to an increase in other cellular components such as proteins and lipids. Although the biomass productivity at $30^{\circ} \mathrm{C}\left(32.05 \mathrm{mg} \cdot \mathrm{L}^{-1}\right.$.day $\left.{ }^{-1}\right)$ was higher than at $35^{\circ} \mathrm{C}\left(24.97 \mathrm{~L}^{-1}\right.$.day $\left.{ }^{-1}\right)$, the cultivation at $35^{\circ} \mathrm{C}$ produced larger quantities of useful compounds such as phenolics, proteins and lipids.

These results showed the antioxidant potential of the phenolics present in the cyanobacterium Arthospira platensis and also indicated that the quantities of phenolics could be increased by altering the culture conditions, suggesting that it was possible to increase the antioxidant potential of $S$. platensis biomass for use as a nutritional supplement. The highest quantities of phenolics were obtained at $35^{\circ} \mathrm{C}$ in medium supplemented with $1.875 \mathrm{~g} . \mathrm{L}^{-1}$ or $2.5 \mathrm{~g} . \mathrm{L}^{-1}$ of sodium nitrate. The phenol-containing methanol extracts obtained from S. platensis grown under these conditions had an antioxidant potential of $29 \%$ when the Spirulina was grown in medium containing 1.875 g. $\mathrm{L}^{-1}$ of sodium nitrate and $35 \%$ in medium containing $2.5 \mathrm{~g} . \mathrm{L}^{-1}$ of sodium nitrate.

\section{RESUMO}

A cianobactéria Spirulina tem sido comercializada e estudada devido as suas propriedades nutricionais e terapêuticas no tratamento de doenças como o câncer, a hipercolesterolemia e a aterosclerose. Determinados compostos presentes na Spirulina, como os compostos fenólicos, a ficocianina e o tocoferol, podem apresentar atividade antioxidante. $\mathrm{O}$ principal objetivo deste trabalho foi avaliar o efeito da temperatura de cultivo e da concentração de nitrogênio no meio de cultivo, sobre o potencial antioxidante da microalga Spirulina (Arthospira) platensis. Quando a microalga foi cultivada a $35^{\circ} \mathrm{C}$ e concentrações de nitrato de sódio de 1,875 g. $\mathrm{L}^{-1}$ ou 2,5 g. $\mathrm{L}^{-1}$, o potencial antioxidante dos extratos obtidos a partir da biomassa, sobre $o$ escurecimento enzimático causado pela peroxidase, foi de $29 \%$ e $35 \%$, respectivamente, sendo a redução no escurecimento relacionada com as quantidades de compostos fenólicos presentes nos extratos. 


\section{REFERENCES}

A.O.A.C. (1995). Official methods of analysis. 16. ed. Association of Official Analytical Chemists. Arlington.

Amaral, D.M.; Moreira, M.; Lobato, M.A.; Abreu, S.M. (1995), Efeito inibidor de substâncias antioxidantes existentes no vinho tinto na aterogênese experimental no coelho. Vittalle, 7, 17-24.

Belay, A.; Ota, Y.; Miyakawa, K.; Shimamatsu, H. (1993), Current knowledge on potential health benefits of Spirulina. Journal of Applied Phycology, 5, 235-241.

Benavente-García, O.; Castillo, J.; Lorente, J.; Ortuño, A.; Del Rio, J.A. (1999), Antioxidant activity of phenolics extracted from Olea europaea L. leaves. Food Chemistry, 68, 457-462.

Costa, J.A.V.; Linde, G.A.; Atala, D.I.P.; Mibielli, G.M.; Kruger, R.T. (2000), Modelling of growth conditions for cyanobacterium Spirulina platensis in microcosms. World Journal of Microbiology \& Biotechnology, 16, 15-18.

Costa, J.A.V.; Colla, L.M.; Duarte Filho, P.F.; Kabke, K.; Weber, A. (2002), Modelling of Spirulina platensis growth in fresh water using response surface methodology. World Journal of Microbiology \& Biotechnology, 18, 603-607.

Costa, J.A.V.; Colla, L.M.; Duarte Filho, P.F. (2003) Spirulina platensis growth in open raceways ponds using fresh water supplemented with carbon, nitrogen and metal ions. Zeitschrift für Naturforsch, 58c, 76-80.

Duval, B.; Shetty, K. (2001), The stimulation of phenolics and antioxidant activity in pea (Pisum sativum) elicited by genetically transformed anise root extract. Journal of Food Biochemistry, 25, 361-377.

Estrada, J.E.; Bescós, P.; Villar Del Fresno, A.M. (2001), Antioxidant activity of different fractions of Spirulina platensis protean extract. Il Farmaco, 56, 497-500.

Folch, J.; Lees, M. (1957), A simple method for isolation and purification of total lipids from animal tissues. Journal of Biological Chemistry, 226, 497-509.

Frankel, E. N.; Waterhouse, A. L.; Teisseche, L. P. (1995), Principal phenolic phytochemicals in selected California wines and their antioxidant activity in inhibiting oxidation of human low-density lipoproteins. Journal of Food Chemistry, 43, 890-894.

Furlong, E.B.; Colla, E.; Bortolato, D.S.; Baish, A.L.M.; Souza-Soares, L.A. de. (2003), Avaliação do potencial de compostos fenólicos em tecidos vegetais. Vetor, 13, 105-114.

Milié, B.L.; Djilas, S.M.; Canadavnovié-Brunet, J.M. (1998), Antioxidative activity of phenolic compounds on the metal-ion breakdown of lipid peroxidation system. Food Chemistry, 61, 443-447.
Miranda, M.S.; Cintra, R.G.; Barros, S.B.M.; Filho, J.M. (1998), Antioxidant activity of the microalga Spirulina maxima. Brazilian Journal of Medical and Biological Research, 31, 1075-1079.

Rechner, A.R.; Spencer, J.P.E.; Kuhnle, G.; Hahn, U.; Rice-Evans, C.A. (2001), Novel biomarkers of the metabolism of caffeic acid derivatives in vivo. Free Radical Biology and Medicine, 30 , 1213-1222.

Singleton, V.L.; Rossi, J.A. (1965), Colorimetry of total phenolics with phosphomolybdic-phosphothungstic acid reagents. American Journal of Enology Viticulture, 16, 144-158.

Valderrama, P.; Marangoni, F.; Clemente, E. (2001), Efeito do tratamento térmico sobre a atividade de peroxidase (POD) e polifenoloxidase (PPO) em maçã (Mallus comunis). Ciência e Tecnologia de Alimentos, 21, 321-325.

Yen, G.C.; Chen, H.Y. (1995), Antioxidant activity of various tea extracts in relation to their antimutagenicity. Journal of Agricultural and Food Chemistry, 43, 27-32.

Yoshino, M.; Murakami, K. (1995), Interaction of iron with polyphenolic compounds: application to antioxidant characterization. Analytical Biochemistry, 257, 40-44.

Zarrouk, C. (1966), Contribution à l'étude d'une cyanophycée. Influence de divers facteurs physiques et chimiques sur la croissance et la photosynthèse de Spirulina maxima. PH.D Thesis, Université De Paris.

Received: November 12, 2004; Revised: December 07, 2005; Accepted: October 25, 2006. 